\title{
Verification of a Numerical Model of the Offshore Wind Turbine From the Alpha Ventus Wind Farm Within OC5 Phase III
}

Popko, Wojciech; Huhn, Matthias L.; Robertson, Amy; Jonkman, Jason M.; Wendt, Fabian; Müller, Kolja ; Kretschmer, Matthias ; Vorpahl, Fabian; Hagen, Torbjørn Ruud; Galinos, Christos

Total number of authors:

33

Published in:

Proceedings of the ASME 2018 37th International Conference on Ocean, Offshore and Arctic Engineering

Link to article, DOI:

10.1115/OMAE2018-77589

Publication date:

2018

Document Version

Publisher's PDF, also known as Version of record

Link back to DTU Orbit

Citation (APA):

Popko, W., Huhn, M. L., Robertson, A., Jonkman, J. M., Wendt, F., Müller, K., Kretschmer, M., Vorpahl, F., Hagen, T. R., Galinos, C., Le Dreff, J-B., Gilbert, P., Auriac, B., Víllora, F. N., Schünemann, P., Bayati, I., Belloli, M., Oh, S., Totsuka, Y., ... Cai, J. (2018). Verification of a Numerical Model of the Offshore Wind Turbine From the Alpha Ventus Wind Farm Within OC5 Phase III. In Proceedings of the ASME 2018 37th International Conference on Ocean, Offshore and Arctic Engineering [V010T09A056] American Society of Mechanical Engineers. https://doi.org/10.1115/OMAE2018-77589

\section{General rights}

Copyright and moral rights for the publications made accessible in the public portal are retained by the authors and/or other copyright owners and it is a condition of accessing publications that users recognise and abide by the legal requirements associated with these rights.

- Users may download and print one copy of any publication from the public portal for the purpose of private study or research.

- You may not further distribute the material or use it for any profit-making activity or commercial gain

- You may freely distribute the URL identifying the publication in the public portal 


\title{
OMAE2018-77589
}

\section{VERIFICATION OF A NUMERICAL MODEL OF THE OFFSHORE WIND TURBINE FROM THE ALPHA VENTUS WIND FARM WITHIN OC5 PHASE III}

\author{
Wojciech Popko, ${ }^{1}$ Matthias L. Huhn, ${ }^{1}$ Amy Robertson, ${ }^{2}$ Jason Jonkman, ${ }^{2}$ Fabian Wendt, ${ }^{2}$ Kolja Müller, ${ }^{3}$ Matthias Kretschmer, ${ }^{3}$ \\ Fabian Vorpahl, ${ }^{4}$ Torbjørn Ruud Hagen, ${ }^{5}$ Christos Galinos, ${ }^{6}$ Jean-Baptiste Le Dreff, ${ }^{7}$ Philippe Gilbert, ${ }^{8}$ Bertrand Auriac, ${ }^{9}$ \\ Francisco Navarro Víllora, ${ }^{10}$ Paul Schünemann, ${ }^{11}$ Ilmas Bayati, ${ }^{12}$ Marco Belloli, ${ }^{12}$ Sho Oh, ${ }^{13}$ Yoshitaka Totsuka, ${ }^{14}$ \\ Jacob Qvist, ${ }^{15}$ Erin Bachynski, ${ }^{16}$ Stian Høegh Sørum, ${ }^{16}$ Paul E. Thomassen, ${ }^{17}$ Hyunkyoung Shin, ${ }^{18}$ \\ Felipe Vittori, ${ }^{19}$ Josean Galván, ${ }^{20}$ Climent Molins, ${ }^{21}$ Paul Bonnet, ${ }^{22}$ Tjeerd van der Zee,${ }^{23}$ Roger Bergua,,${ }^{24}$ \\ Kai Wang, ${ }^{24}$ Pengcheng Fu, ${ }^{25}$ Jifeng Cai ${ }^{25}$
}

${ }^{1}$ Fraunhofer Institute for Wind Energy Systems IWES, Division Wind Turbine and System Technology, 27572 Bremerhaven, Germany wojciech.popko@iwes.fraunhofer.de

\begin{abstract}
${ }^{2}$ National Renewable Energy Laboratory, Golden, CO, USA, ${ }^{3}$ University of Stuttgart, Stuttgart Wind Energy, Stuttgart, Germany,
${ }^{4}$ Senvion, Osnabrück, Germany, ${ }^{5}$ OWEC Tower AS, Oslo, Norway, ${ }^{6}$ Technical University of Denmark, Department of Wind Energy, Roskilde, Denmark ${ }^{7}$ Electricité de France, Recherche et Développement, Palaiseau, France, ${ }^{8}$ IFP Energies Nouvelles, Solaize, France,

${ }^{9}$ Principia, La Ciotat, France, ${ }^{10}$ Siemens Gamesa Renewable Energy, Hamburg, Germany, ${ }^{11}$ University of Rostock, Endowed Chair of Wind Energy Technology, Rostock, Germany, ${ }^{12}$ Politecnico di Milano, Department of Mechanical Engineering, Milano, Italy, ${ }^{13} \mathrm{Nippon}$ Kaiji Kyokai, Tokyo, Japan, ${ }^{14}$ Wind Energy Institute of Tokyo Inc., Tokyo, Japan, ${ }^{15} 4$ Subsea, Hvalstad, Norway, ${ }^{16}$ Norwegian University of Science and Technology, Department of Marine Technology, Trondheim, Norway, ${ }^{17}$ Simis AS, Trondheim, Norway, ${ }^{18}$ University of Ulsan, School of Naval Architecture and Ocean Engineering, Ulsan, The Republic of Korea, ${ }^{19}$ National Renewable Energy Centre, Sarriguren,

Spain, ${ }^{20}$ TECNALIA, Derio, Spain, ${ }^{21}$ Polytechnic University of Catalonia, Barcelona, Spain, ${ }^{22}$ Siemens Industry Software, Cornellà de Llobregat, Spain, ${ }^{23}$ Knowledge Centre WMC, Wieringerwerf, The Netherlands, ${ }^{24}$ Envision Energy Limited, Shanghai, China, ${ }^{25}$ China General Certification Center, Beijing, China
\end{abstract}

\section{ABSTRACT}

The main objective of the Offshore Code Comparison Collaboration Continuation, with Correlation (OC5) project, is validation of aero-hydro-servo-elastic simulation tools for offshore wind turbines (OWTs) through comparison of simulated results to the response data of physical systems. Phase III of the OC5 project analyzes the Senvion $5 M$ wind turbine supported by the OWEC Quattropod from the alpha ventus offshore wind farm. This paper shows results of the verification of the OWT models (code-to-code comparison). A subsequent publication will focus on their validation (comparison of simulated results to measured physical system response data). Based on the available data, the participants of Phase III set up numerical models of the OWT in their simulation tools. It was necessary to verify and to tune these models. The verification and tuning were performed against an OWT model available at the University of Stuttgart - Stuttgart Wind Energy (SWE) and documentation provided by Senvion and OWEC Tower. A very good match was achieved between the results from the reference SWE model and models set up by OC5 Phase III participants.

\section{INTRODUCTION}

The Offshore Code Comparison Collaboration Continuation, with Correlation (OC5) project [1], which operates under the International Energy Agency (IEA) Wind Task 30 is the follow-up project of OC3 and OC4, which ran from 2005 to 2009 